\title{
Immunohistochemical expression of p53, BCL-2, BAX and VEGFR1 proteins in nephroblastomas
}

\author{
A expressão imuno-bistoquímica das proteinas p53, BCL-2, BAXe \\ VEGFR1 em nefroblastomas
}

Ana Paula Percicote ${ }^{1}$; Fernanda El Ghoz Leme ${ }^{2}$; Tammy Vernalha Rocha Almeida ${ }^{2}$;

Ana Karyn Ehrenfried Freitas²; Elizabeth Schneider Gugelmin ${ }^{3}$; Lúcia de Noronha ${ }^{4}$

\begin{abstract}
Introduction: Nephroblastoma or Wilms' tumor is the most frequent renal cancer in children. Although its prognosis is favorable for most patients, it may relapse or have a fatal outcome. The characterization of risk groups by applying immunohistochemical biomarkers aims to adapt the treatment to its corresponding group as well as to reduce relapses and fatal outcome. p53, B-cell lymphoma 2 (BCL-2), BCL-2 associated protein X (BAX) and vascular endothelial growth factor receptor 1 (VEGFR1) are among the most widely studied biomarkers, which are related to the apoptotic pathway, DNA repair and neovascularization. Objective: The objective of this study is to assess the immunohistochemical expression of p53, BCL-2, BAX and VEGFR1 in samples of human nephroblastoma and to correlate them with clinicopathological prognostic factors. Material and methods: Twenty-nine surgical specimens of nephroblastoma diagnosed from 1994 to 2007 were selected from the Anatomopathological Service of two hospitals in Curitiba. The immunohistochemical analysis of tissue microarrays was performed through immunoperoxidase staining and the yielded results were compared with clinicopathological prognostic factors. Results: The major immunohistochemical expression of VEGFR1 in blastema and epithelium presented positive association with the risk group. Hence this may be related to higher vascular neoplastic invasion apparently caused by the endothelial growth factor, which maximizes the chances of metastasis and ultimately changes tumor staging, risk group and clinical evolution. Conclusions: The immunohistochemical expression of VEGFR1 substantiated a directly proportional association with the nephroblastoma risk group.
\end{abstract}

Key words: Wilms' tumor; p53; BCL-2; BAX; VEGFR1.

\section{INTRODUCTION}

Wilms' tumor or nephroblastoma is a malignant embryonic neoplasia derived from nephrogenic blastema cells. It is the most frequent renal neoplasia among children, corresponding to $98 \%$ of renal tumors within this age group. Wilms' tumor microscopy presents histological components similar to those found during nephrogenesis such as blastema, epithelium and stroma in varied proportions ${ }^{(5)}$.

Despite the excellent prognostic achieved with current therapeutic approaches, $10 \%$ to $15 \%$ of patients may have relapses and reduced survival rates. With the aim to stratify patients into risk groups that best reflect the biological behavior of Wilms' tumor and to implement better therapeutic approaches, several studies have tried to analyze the molecular mechanisms involved in its complex pathogenesis ${ }^{(18,20)}$. Potential biomarkers for Wilms' tumor have been described in the medical literature. It is particularly worth mentioning those that are involved in cellular proliferation, apoptosis and angiogenesis, mainly p53. B-cell lymphoma 2 (BCK-2), BCL-2 associated protein X (BAX) and vascular endothelial growth factor receptor 1 (VEGFR1) ${ }^{(13,23,30)}$.

In this study, we observed the immunohistochemical expression of p53, BCL-2, BAX and VEGFR1 markers in 29 Wilms' tumors in order to propose new biomarkers applicable to diagnostic, prognostic and therapeutic approaches to this neoplasia.

\section{MATERIAL AND METHODS}

\section{Sample selection}

29 patients with Wilms' tumor were selected for this study, from which 15 of them were from Hospital Infantil Pequeno Príncipe (1998

First submission on $03 / 07 / 12$; last submission on 26/12/12; accepted for publication on 20/12/12; published on 20/02/13

1. Master's candidate at the Post Graduation Program of Microbiology, Parasitology and Pathology from Universidade Federal do Paraná (UFPR).

2. Graduate student at UFPR.

3. Pathologist at Hospital Infantil Pequeno Príncipe-PR.

4. Doctor in Pediatric Dermatopathology from UFPR; pathologist at UFPR Clinical Hospital 
to 2007) and 14 of them were from Universidade Federal do Paraná Clinical Hospital-UFPRCH (1994 to 2007). The staging and treatment were according to the guidelines proposed by Sociétè Internationale d'Oncologie Pediatrique (SIOP). The study was approved by the Ethics Research Committees from both institutions.

\section{Tissue microarray construction (TMAs)}

The review of histological hematoxylin and eosin (HE) slides was conducted and the samples were classified as to histological type, risk group, presence or absence of anaplasia, necrosis, regressive alterations and nephrogenic rests.

The histopathological classification of samples was according to Sociétè Internationale d'Oncologie Pediatrique Working Classification of Renal Tumors (2001), which categorizes the tumors into three risk groups: low, intermediate and high risk ${ }^{(34)}$. This classification is based on the evaluation of Wilms' tumor histological components (blastema, stroma and epithelium) and assessment of histological alterations caused by pre-operative chemotherapy.

We allocated three representative areas of Wilms' tumor histological components (blastema, stroma and epithelium) and one area of non tumoral renal tissue for tissue microarray construction $(\text { TMA })^{(9)}$.

\section{Immunohistochemistry}

Histological sections ( $4 \mu \mathrm{m}$ thick) were obtained from five receptor blocks and assessed by immunohistochemistry. Slides were deparaffinized with xylene $\left(37^{\circ} \mathrm{C}\right)$, dehydrated with successive alcohol baths and rehydrated with water. Methyl alcohol and peroxide were applied in the first block of endogenous peroxidase and distilled water and peroxide in the second block. Subsequently, incubation was performed with the five primary antibodies chosen for this study: BCL-2 (clone 124, monoclonal, Dako $\left.{ }^{\circledR}, 1: 200\right)$, BAX (policlonal, Dako $\left.^{\circledR}, 1: 50\right)$, VEGFR1 (policlonal, Thermo Scientific ${ }^{\circledR}, 1: 50$ ) and p53 (clone D0-7, monoclonal, Dako ${ }^{\circledR}, 1: 200$ ). The secondary antibody (AdvanceTM HRP Dako ${ }^{\circledR}$ ), associated with dextran polymer, was incubated with the material for 30 minutes at room temperature. 3-3'-diaminobenzidine (DAB) and substrate (DAB + liquid DakoCytomation ${ }^{\circledR}$ chromogenic substrate system Dako ${ }^{\circledR}$ ) were added and counterstaining was performed with Mayer hematoxylin, followed by dehydration with ethylic alcohol (100\%) and clearing with xylene. Canada balsam was used for slide mounts.

Concomitant reactions with positive and negative external controls were carried out for each antibody. The latter were obtained through primary antibody omission. The immunohistochemical expression of the analyzed proteins (p53, BCL-2, BAX and VEGFR1) was assessed by quantifying the number of positive tumor cells in a count of 100 tumor cells per high power field, considering that there were five high power fields per tumor element (blastema, epithelium and stroma). This assessment was compiled and the mean values for each neoplasia represented the mean immunohistochemical expression for each studied protein. The analysis of each tumor component (blastema, epithelium and stroma) was carried out as well.

\section{Clinical records review}

The following clinicopathological data were obtained from the review of clinical records: patients' gender, age at diagnosis, clinical staging at diagnosis, presence or absence of metastasis at diagnosis, undergone treatment, tumor weight and patients' clinical evolution.

\section{Statistical analysis}

Mann-Whitney non parametric method was applied for the comparison between two groups as to quantitative variables, whereas Kruskal-Wallis non parametric test was applied for the comparison within more groups due to the fact that the population did not present normal distribution. $p$ values $<0.05$ showed statistical significance. The data were assessed with Statistica program v.8.0.

\section{RESULTS}

Concerning gender, $55.2 \%$ were male and $44.8 \%$ were female. $62.1 \%$ of patients were $\geq 24$ months old and $37.9 \%$ were $<24$ months old. As to staging, eight patients (27.6\%) were in stage I, four (13.8\%) were in stage II, ten (34.5\%) in stage III and seven (24.1\%) in stage IV. Four out of 29 patients (13.8\%) belonged to the high risk group and $25(86.2 \%)$ to the intermediate risk group. The mean follow-up time was 85.6 months.

Other relevant clinical pathological variables are demonstrated in Table 1.

The immunohistochemical expression of each antibody was compared with clinical pathological variables (Table 2).

Mean immunohistochemical expression of BAX was higher at stage I (32.9) in comparison with stages II (12.5), III (11.3) and IV (27.0) with statistical significance $(p=0.054)$. Mean immunohistochemical expression of VEGFR1 in stage IV (25.3) was higher in comparison with stages I (21.2), II (5.1) and III (9.8) with statistical relevance $(p=0.079)$. Mean immunohistochemical expression in stages II, III and IV was not statiscally different among each other

Mean immunoexpression of BCL-2 was higher among healthy patients (13.6) in comparison with relapse/fatal outcome group (4.3) with tendency to statistical relevance $(p=0.075)$. Mean immunoexpression of 533 was higher in tumors treated with preoperative chemotherapy (3.7) when compared with tumors not treated with this procedure (2.2) with statistical significance $(\phi=0.020)$.

BAX and VEGFR1 markers indicated higher mean immunoexpression in tumors weighing less than $550 \mathrm{~g}$ (29.9 and 
TABLE 1 - Descriptive statistics of all clinical pathological variables

\begin{tabular}{ccc}
\hline Variable & Category & $n(\%)$ \\
\hline Clinical evolution $(n=27)^{*}$ & no disease & $22(81.5)$ \\
Metastasis $(n=29)$ & relapse/fatal outcome & $5(18.5)$ \\
& No & $22(75.8)$ \\
Preoperative CT $(n=29)$ & Yes & $7(24.2)$ \\
& Yes & $18(62.1)$ \\
Anaplasia $(n=29)$ & No & $11(37.9)$ \\
& Present & $2(6.9)$ \\
Nephrogenic rests $(n=29)$ & Absent & $27(93.1)$ \\
& Yes & $6(20.7)$ \\
\hline
\end{tabular}

*: two cases were transferred to a another hospital during the study discontinuing follow-up.

CT: chemotherapy.

TABLE 2 - Correlation between mean immunohistochemical expression of p53, BCL-2, BAX and VEGFR1

(mean number of positive cells per 100 tumor cells) and staging, risk group, patient's evolution, age at diagnosis, tumor weight, presence/absence of anaplasia and presence/absence of preoperative chemotherapy

\begin{tabular}{|c|c|c|c|c|c|}
\hline \multicolumn{2}{|c|}{ Variable } & \multirow{2}{*}{$\begin{array}{c}\mathrm{p} 53 \\
2.3\end{array}$} & \multirow{2}{*}{$\begin{array}{c}\text { BCL-2 } \\
16.2\end{array}$} & \multirow{2}{*}{$\frac{\text { BAX }}{32.9^{\mathrm{a}}}$} & \multirow{2}{*}{$\begin{array}{c}\text { VEGFR1 } \\
21.2\end{array}$} \\
\hline Staging & Stage I & & & & \\
\hline & Stage II & 1.9 & 1.6 & 12.5 & 5.1 \\
\hline & Stage III & 5.7 & 11.3 & 11.3 & 9.8 \\
\hline & Stage IV & 1.1 & 12.6 & 27.0 & $25.3^{\mathrm{b}}$ \\
\hline \multirow[t]{2}{*}{ Risk group } & Intermediate & 1.8 & 12.6 & 22.7 & 15.9 \\
\hline & High & 11.6 & 5.6 & 12.1 & 17.2 \\
\hline \multirow[t]{2}{*}{ Clinical evolution } & No disease & 4 & 13.6 & 22.2 & 15.5 \\
\hline & Fatal outcome/relapse & 0.7 & $4.3^{c}$ & 19.0 & 16.5 \\
\hline \multirow[t]{2}{*}{ Age } & $\geq 24$ months & 3.7 & 11.2 & 18.5 & 15.2 \\
\hline & $<24$ months & 2.2 & 12.2 & 25.6 & 17.5 \\
\hline \multirow[t]{2}{*}{ Tumor weight } & $<550 \mathrm{~g}$ & 2.2 & 17.2 & 29.9 & 24.2 \\
\hline & $\geq 550 \mathrm{~g}$ & 5.9 & $6.7^{d}$ & $12.4^{e}$ & $9.1^{\mathrm{f}}$ \\
\hline \multirow[t]{2}{*}{ Anaplasia } & Absent & 1.7 & 11.8 & 21.8 & 14.7 \\
\hline & Present & 23.2 & 9.3 & 14 & 34.4 \\
\hline \multirow[t]{2}{*}{ Preoperative CT } & No & 2.2 & 6.9 & 13.5 & 12 \\
\hline & Yes & $3.7^{\mathrm{g}}$ & 14.5 & 25.9 & 18.6 \\
\hline
\end{tabular}

$a: \mathrm{p}=0.054 ;^{b}: \mathrm{p}=0.079 ;{ }^{c}: \mathrm{p}=0.075 ;{ }^{d}: \mathrm{p}=0.095 ;{ }^{e}: \mathrm{p}=0.026 ;{ }^{f}: \mathrm{p}=0.008 ;{ }^{g}: \mathrm{p}=0.020$

BCL-2: B-cell lymphoma 2; BAX: BCL-2 associated protein X; VEGFR1: vascular endothelial growth factor receptor 1; CT: chemotherapy.

24.2, respectively) when compared with tumors weighing more than $550 \mathrm{~g}$ (12.4 and 9.1, respectively) with statistical significance $(\phi=$ 0.026 and $p=0.008$, respectively).

The comparison between early stages (I and II) and advanced stages (II and IV) as to the studied markers did not reveal any statistical significance. The Figure shows the immunohistochemical expression of the studied markers (p53, BCL-2, BAX and VEGFR1) in each histological component of the neoplasia (blastema, epithelium and stroma) and in the non neoplastic renal sample.

The immunohistochemical expression of each antibody per Wilms's tumor histological component (blastema, stroma and epithelium) was compared with the same clinical pathological variables (Table 3).

In the immunoexpression assessment of each antibody per Wilms' tumor histological component (blastema, epithelium and 
TABLE 3 - Correlation between mean immunohistochemical expression of p53, BCL-2, BAX and VEGFR1 (mean number of positive cells per 100 tumor cells) and staging, risk group, patient's evolution, age at diagnosis, tumor weight, presence/absence of anaplasia and presence/absence of preoperative chemotherapy according to each histological neoplastic component (blastema, epithelium and stroma)

\begin{tabular}{|c|c|c|c|c|c|c|c|c|c|c|c|c|c|c|c|c|c|c|}
\hline & & \multicolumn{3}{|c|}{ Risk group } & \multicolumn{5}{|c|}{ Staging } & \multicolumn{3}{|c|}{ Clinical evolution } & \multicolumn{3}{|c|}{ Anaplasia } & \multicolumn{3}{|c|}{ preoperative CT } \\
\hline & & Intermediate & High & $p$ & I & II & III & IV & $p$ & No disease & $\begin{array}{c}\text { Fatal outcome/ } \\
\text { relapse }\end{array}$ & $p$ & Absent & Present & $p$ & No & Yes & $p$ \\
\hline \multirow{3}{*}{$\mathrm{p} 53$} & Blastema & 2.1 & 15.2 & 0.874 & 0.8 & 4.5 & 7.4 & 1.6 & 0.302 & 5 & 0.8 & 0.357 & 1.9 & 30.4 & 0.392 & 3.4 & 4.4 & 0.010 \\
\hline & Epithelium & 1.3 & 23.2 & 0.317 & 2.1 & 0.7 & 6.4 & 1.2 & 0.622 & 3.7 & 1.1 & 0.817 & 1.3 & 46.4 & 0.041 & 1.4 & 4.2 & 0.075 \\
\hline & Stroma & 0.9 & 10.8 & 0.572 & 0.2 & 0.6 & 4.6 & 0.8 & 0.785 & 2.4 & 1.1 & 0.785 & 0.9 & 32.4 & 0.032 & 1.8 & 2.3 & 0.118 \\
\hline \multirow{3}{*}{ BCL-2 } & Blastema & 6 & 13.8 & 0.771 & 9.6 & 0.7 & 10.1 & 4.3 & 0.057 & 9 & 0.6 & 0.130 & 7 & 9.6 & 1 & 2.5 & 10.6 & 0.176 \\
\hline & Epithelium & 19 & 8.6 & 0.694 & 19.8 & 0 & 19.2 & 27.1 & 0.096 & 22.4 & 6.1 & 0.782 & 18.3 & 17.2 & 0.540 & 14.3 & 21.1 & 0.652 \\
\hline & Stroma & 8.3 & 10.2 & 0.613 & 9.1 & 4 & 9.7 & 8.9 & 0.709 & 6.2 & 18.6 & 0.782 & 8 & 19.6 & 0.327 & 3.9 & 12.1 & 0.087 \\
\hline \multirow{3}{*}{ BAX } & Blastema & 18.3 & 14.4 & 0.886 & 27.7 & 17.6 & 6.8 & 24.8 & 0.229 & 18.2 & 24.1 & 0.163 & 18.2 & 12.5 & 0.808 & 8.2 & 24.3 & 0.109 \\
\hline & Epithelium & 36.4 & 16.5 & 0.295 & 52.9 & 8.0 & 19 & 43.4 & 0.016 & 33.7 & 36 & 0.684 & 36.2 & 0 & 0.129 & 25.5 & 41.3 & 0.177 \\
\hline & Stroma & 12.5 & 4.8 & 0.376 & 15.2 & 4.4 & 10.1 & 15.6 & 0.167 & 11.5 & 7.8 & 0.895 & 11.8 & 9 & 0.789 & 5.5 & 16.2 & 0.019 \\
\hline \multirow{3}{*}{ VEGFR-1 } & Blastema & 0 & 14.6 & 0.016 & 0 & 0 & 0 & 8.3 & 0.414 & 0 & 14.5 & 0.021 & 0 & 29.1 & 0.0004 & 0 & 3.6 & 0.407 \\
\hline & Epithelium & 35 & 5.6 & 0.444 & 46.9 & 15.8 & 19.7 & 50.1 & 0.090 & 38.3 & 7.4 & 0.067 & 35 & 5.6 & 0.444 & 31.3 & 35.9 & 0.890 \\
\hline & Stroma & 1.8 & 8.8 & 0.637 & 11.5 & 0 & 12.1 & 17.9 & 0.263 & 9.2 & 15.6 & 0.962 & 10.8 & 26.4 & 0.285 & 4.6 & 16.4 & 0.331 \\
\hline
\end{tabular}

BCL-2: B-cell lymphoma 2; BAX: BCL-2 associated protein X; VEGFR1: vascular endothelial growth factor receptor 1; CT: chemotherapy.

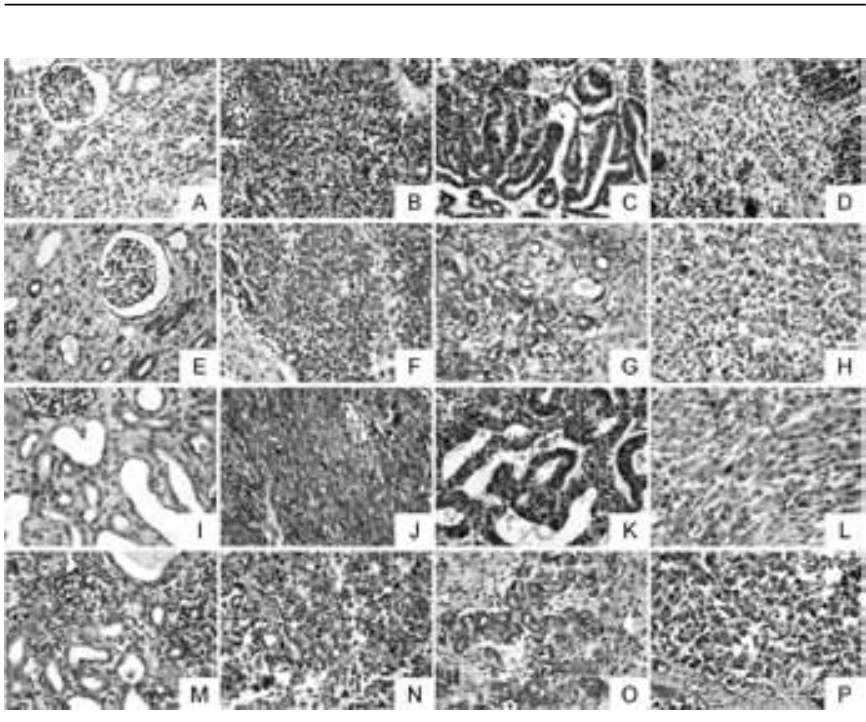

FIGURE - Immunoexpression of $p 53$ (A, B, C and D), BCL-2 (E, F, G and H), BAX (I, J, $K$ and $L)$ and VEGFR1 $(M, N, O$ e P) in non-neoplastic renal tissue and in Wilms' tumor bistological components (blastema, epithelium and stroma).

Note that immunopositivity for $p 53$ and BCL-2 is expressed in the nucleus or perinucleus, whereas BAX and VEGFR1 are expressed in the cytoplasm.

BCL-2: B-cell lymphoma 2; VEGFR1: vascular endothelial growth factor receptor 1; BAX BCL-2 associated protein $X$.

stroma), p53 marker showed a higher mean expression in blastema of tumors treated with preoperative chemotherapy $(\phi=0.010)$ and in epithelial and stromal components of tumors with anaplasia ( $p=0.041$ and $p=0.032$, respectively).

Mean immunoexpression of BAX was higher in the epithelial component in stage I $(52.9 ; p=0.016)$ in comparison with stages II ${ }^{(8)}$,
III (19) and IV (43.4). Moreover, it had higher mean expression in the stromal component of cases treated with preoperative chemotherapy $(p=0.019)$.

Mean immunoexpression of VEGFR in blastema was higher in high risk tumors $(p=0.016)$, in tumors with clinical evolution to relapse/fatal outcome $(\phi=0.021)$ and tumors with anaplasia $(p=0.0004)$.

\section{DISCUSSION}

In the selected population, $86.21 \%$ of patients were younger than 5 years of age, which corroborates literature findings. Mean age at diagnosis was similarly reported by other authors (2.98 years ${ }^{(5)}$.

The frequency of nephroblastomas is virtually equal in both genders, considering the fact that some studies evince a slight predominance in the female group, which was also confirmed in the present study ${ }^{(4,5,11)}$

As far as clinical presentations are concerned, the presence of abdominal mass was predominant $(82.76 \%)$, which is similarly corroborated by the literature $^{(17,20)}$.

In this sample, nephrogenic rests, which consist of post-natal embryonic cells or their derivatives, were found in 6 cases $(20.7 \%)$. They are regarded as Wilms' tumor precursor lesions with different clinical and epidemiological aspects and they are also associated with over $42 \%$ of these tumors, though they are not related to tumoral relapse rates ${ }^{(3,6,28)}$.

According to the cooperative groups (National Wilms Tumor Study Group and SIOP), the stratification of Wilms's tumor patients into risk groups and stages guides the treatment administered to the patients and also improves the assessment of clinical evolution. However, despite the fact that the risk groups and stages are generally 
able to predict the clinical evolution accurately, some patients show an unexpected clinical course by either developing relapses in early stages or by presenting no relapses in advanced stages.

We strive for a better understanding of molecular processes over tumoral pathogenesis in order to grasp the heterogeneous biological behavioral of the neoplasias included in the same risk group. It is particularly worth mentioning the researches into apoptosis mechanisms, cellular proliferation and angiogenesis. A better understanding of these molecules and tumoral behavior may enable us to adapt treatments and develop new medications and therapeutic approaches. Not only could these molecules or biomarkers predict patients' clinical evolution as to risk group, but they could also enable an early treatment adjustment to the clinical course. p53, BCL-2, BAX and VEGF1 are particularly worth mentioning as possible biomarkers for Wilms' tumor ${ }^{(27)}$.

Iimmunohistochemical expression of $\mathrm{p} 53$ is reported as an anaplasia marker in Wilms' tumors, whereas in tumors with favorable histology, there are conflicting results ${ }^{(8,23,29,31)}$. In the present study, immunohistochemical expression of $\mathrm{p} 53$ was detected in $37.9 \%$ of the cases, from which one case (9\%) presented histologically diffuse anaplasia. The immunohistochemical expression per tumor component, similarly reported by other authors, was higher in the blastema and epithelial components. Analyzing positivity for epithelial and stromal components separately, we observed a higher expression in tumors with anaplasia, which evinces that $p 53$ would be a marker for anaplasia in Wilms' tumors ${ }^{(7,23,29)}$.

Srednietal. ${ }^{(31)}$ investigated 97 patients with Wilms' tumor in stages $\mathrm{I}-\mathrm{V}$, from which 13 (13.4\%) were positive for p53 immunoexpression and two tumors (15.4\%) from this subgroup presented anaplasia at histology. Furthermore, in our study p53 immunoexpression correlated with preoperative chemotherapy in both mean and isolated immunoexpression in the blastema component and it was higher in cases with previous chemotherapy ${ }^{(8,16,29,31)}$. Although some authors have discussed the effects of preoperative chemotherapy on $p 53$ immunoexpression, this topic arouses controversy in the medical literature. It is believed that preoperative chemotherapy selects cellular lineages with $\mathrm{p} 53$ immunopositivity, which causes necrosis of immunonegative cells ${ }^{(8,31)}$. On the other hand, Sredni et al. ${ }^{(31)}$ did not find positivity in tumors treated with preoperative chemotherapy and Lahoti et al. ${ }^{(23)}$ did not observe any difference in terms of immunohistochemical expression in specimens before and after chemotherapy.

Over expressed BCL-2 causes carcinogenesis by inhibiting the apoptosis mechanism. When programmed cellular death is impaired, the cell life span increases, which promotes neoplastic progression and radiotherapy/chemotherapy resistance ${ }^{(13)}$. Nevertheless, it is known that BCL-2 expression increases according to the differentiation rate of lesions. Hence high BCL-2 expression rates may be present in well differentiated lesions, which would intrinsically have a better prognosis ${ }^{(2,26)}$. The immunoexpression of BCL-2 in the blastema component, which was assessed by Ghanem et $a l^{(13)}$ in Wilms' tumor treated with preoperative chemotherapy, proved to be a useful tool in the correlation with clinical course. In this study, mean immunoexpression of BCL-2 was different within the clinical evolution groups (healthy or relapse/fatal outcome). Besides, there was a higher BCL-2 expression in the healthy group, results not corroborated by the reviewed literature ${ }^{(13)}$. Moreover, its immunoexpression was higher in tumors with less than $550 \mathrm{~g}$, which are also associated with favorable prognosis ${ }^{(35)}$.

BAX pro-apoptotic protein, which belongs to BCL-2 family, was identified in association with BCL-2 through co-immunoprecipitation assays ${ }^{(25)}$. The immunohistochemical expression of BAX in the epithelial component was associated with early clinical stages. Krajewski $e t a l{ }^{(22)}$ noted poor prognostic evolution in mammary carcinomas correlated with reduction of BAX immunoexpression. Germ cell tumors in children demonstrated correlation between the absence of BAX expression and poor prognosis ${ }^{(1)}$, whereas Wilms' tumor patients with higher staging showed reduction in BAX expression ${ }^{(13)}$.

In this investigation, the highest positivity was detected in stage I when compared with other stages. Additionally, BAX immunoexpression in stroma was higher in cases with preoperative chemotherapy and mean immunoexpression of BAX was higher in tumors weighing less than $550 \mathrm{~g}$. It is acknowledged that chemotherapeutic agents sensitize neoplastic cells for a higher apoptotic activity, hence its higher expression in cases with preoperative chemotherapy ${ }^{(1,21,33)}$.

The angiogenesis is fundamental for tumor growth and it is under regulatory effects of a wide variety of angiogenic factors, namely vascular endothelial growth factor (VEGF) and its receptors ${ }^{(14)}$. VEGF action on endothelial cell receptors promotes angiogenesis as well as it induces the expression of antiapoptotic proteins. Furthermore, it stimulates the attraction of inflammatory cells and it promotes protease expression that operate on the degradation of extracellular matrix ${ }^{(32)}$. VEGFR1 gene or fms-related tyrosine kinase 1 (Flt-1) is expressed in pediatric neoplasias as medulloblastoma. neuroblastoma and rhabdomyosarcoma and it is linked with poor prognosis in these tumors ${ }^{(10,12,24,30)}$.

In this research, tumors weighing less than $550 \mathrm{~g}$ showed higher VEGFR1 immunohistochemical expression. It was observed that its immunohistochemical expression in the cytoplasm of blastema neoplastic cells was correlated with risk group, clinical course and anaplasia, being higher in the high risk group among patients with relapse or fatal outcome and tumors with anaplasia. The role of VEGFR1 in the progression of Wilms' tumors had

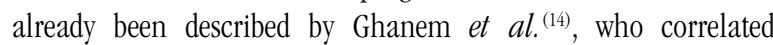
VEGFR1 immunoexpression with clinical progression and fatal outcome. These findings suggest the participation of these cells in tumoral neovascularization. Although target therapy for VEGF is available, recent studies have demonstrated that its action occurs on endothelial tumoral cells and not on tumoral cells ${ }^{(19)}$.

\section{CONCLUSION}

It was concluded that mean VEGFR1 immunoexpression was higher in tumors weighing less than $550 \mathrm{~g}$ and the positivity in the blastema component was higher in the high risk group, in tumors with anaplasia and among patients with relapse/fatal outcome. 
The immunohistochemical expression of $p 53$ was higher in tumors not treated with preoperative chemotherapy. As to BCL-2, healthy patients and tumors weighing less that $550 \mathrm{~g}$ had a higher protein immunoexpression, whereas BAS immunoexpression was higher in tumors weighing less than $550 \mathrm{~g}$. Therefore, these markers may be applied to predict the biological behavior of Wilms' tumor, mainly

\begin{abstract}
RESUMO
Introdução: O nefroblastoma, ou tumor de Wilms, é a neoplasia renal mais frequente na infância. Embora o prognóstico seja favorável para a maioria dos pacientes, muitos evoluem para recidiva ou óbito. A caracterização de grupos de risco por meio de marcadores imuno-histoquímicos tem por objetivo adequar o tratamento ao grupo de risco e reduzir recidivas e óbitos. Entre os marcadores mais estudados estão p53, B-cell lymphoma 2 (BCL-2), BCL-2 associated protein X (BAX) e fator de crescimento vascular endotelial e seu receptor 1 (VEGFR1), relacionados com a via apoptótica, o reparo do ácido desoxirribonucleico (DNA) e a neovascularização. Objetivo: O objetivo deste estudo é avaliar a expressão imuno-bistoquímica de p53, BCL-2, BAX e VEGFR1 em amostras de nefroblastoma bumano e correlacioná-las com fatores prognósticos clínico-patológicos. Material e método: Foram utilizadas 29 amostras de nefroblastomas retiradas dos Serviços de Anatomia Patológica de dois hospitais de Curitiba, com diagnósticos entre 1994 e 2007. Por meio da técnica de imunoperoxidase, com as amostras em arranjo tecidual em matriz, realizou-se análise da imuno-bistoquímica desses marcadores e sua comparação com fatores prognósticos clínico-patológicos. Resultados: A maior imunoexpressão de VEGFR1 nos componentes blastematoso e epitelial mostrou associação positiva ao grupo de risco, sendo que isso poderia estar relacionado com a maior capacidade de invasão vascular neoplásica que pode ser conferida por esse fator de crescimento endotelial, aumentando, assim, as chances de metástases e alterando o estadimento, o grupo de risco e a evolução clínica. Conclusão: A expressão imuno-bistoquímica aumentada de VEGFR1 mostrou associação diretamente proporcional ao grupo de risco dos pacientes com nefroblastoma.
\end{abstract}

Unitermos: tumor de Wilms; p53; BCL-2; BAX; VEGFR1.

VEGFR1, which may have both therapeutic and prognostic values.

\section{REFERENCES}

1. ADDE0, R. et al. Bax mutation and overexpression inversely correlate with immature phenotype and prognosis of childhood germ cell tumors. Oncol Rep, v. 17, n. 5, p. 1155-61, 2007.

2. ANTONSSON, B.; MARTINOU, J. C. The Bcl-2 protein family. Exp Cell Res, v. 256, n. 1, p. $50-7,2000$

3. BECKWITH, J. B. Nephrogenic rests and the pathogenesis of Wilms tumor: developmental and clinical considerations. Am J Med Genet, v. 79, n. 4, p. 268-73, 1998.

4. BRESLOW, N. E. et al. Age distribution of Wilms' tumor: report from the National Wilms' tumor Study. Cancer Research, v. 48, n. 6, p. 1653-7, 1988.

5. BRESLOW, N. et al. Epidemiology of Wilms tumor. Med Pediatr Oncol, v. 21, n. 3, p. 172-81, 1993.

6. BRESLOW, N. E. et al. Age distributions, birth weights, nephrogenic rests and heterogeneity in the pathogenesis of Wilms tumor. Pediatr Blood Cancer, v. 47, n. 3, p. 260-7, 2006.

7. CHEAH, P. L.; LOOI, L. M.; CHAN, L. L. Immunohistochemical expression of p53 proteins in Wilms' tumour: a possible association with the histological prognostic parameter of anaplasia. Histopathology, v. 28, n. 1, p. 49-54, 1996.

8. D'ANGELO, M. F. et al. p53 immunopositivity in histologically favorable Wilms tumor is not related to stage at presentation or to biological aggression. J Urol, v. 169, n. 5, p. 1815-7, 2003.

9. DO CARMO DEBUR, M. et al. Immunohistochemical assessment of respiratory viruses in necropsy samples from lethal non-pandemic seasonal respiratory infections. J Clin Pathol, v. 63, n. 10, p. 930-4, 2010.
10. FAKHARI, M. et al. Upregulation of vascular endothelial growth factor receptors is associated with advanced neuroblastoma. J Pediatr Surg, v. 37, n. 4, p. 582-7, 2002.

11. FRANCO, E. L. et al. Epidemiological and clinical correlations with genetic characteristics of Wilms' tumor: results of the Brazilian Wilms' tumor study group. Int J Cancer, v. 48, n. 5, p. 641-6, 1991.

12. GEE, M. F. W. et al. Vascular endothelial growth factor acts in an autocrine manner in rhabdomyosarcoma cell lines and can be inhibited with all-transretinoic acid. Oncogene, v. 24, n. 54, p. 8025-37, 2005.

13. GHANEM, M. A. et al. The prognostic significance of apoptosis-associated proteins BCL-2, BAX and BCL-X in clinical nephroblastoma. Br J Cancer, v. 85 , n. 10 , p. $1557-63,2001$.

14. GHANEM, M. A. et al. Expression and prognostic relevance of vascular endothelial growth factor (VEGF) and its receptor (FLT-1) in nephroblastoma. J Clin Pathol, v. 56, n. 2, p. 107-13, 2003.

15. GHANEM, M. A. et al. The predictive value of immunohistochemical markers in untreated Wilms' tumour: are they useful? World J Urol, 2011.

16. GOVENDER, D. et al. p53 protein expression in nephroblastomas: a predictor of poor prognosis. Br J Cancer, v. 77, n. 2, p. 314-8, 1998.

17. GREEN, D. M. et al. Treatment of children with stage IV favorable histology Wilms tumor: a report from the National Wilms Tumor Study Group. Med Pediatr Oncol, v. 26. n. 3, p. 147-52, 1996.

18. HUANG, C. et al. Predicting relapse in favorable histology Wilms tumor using gene expression analysis: a report from the Renal Tumor Committee of the Children's Oncology Group. Clin Cancer Res, v. 15, n. 5, p. 1770-8, 2009.

19. HUANG, D. et al. Sunitinib acts primarily on tumor endothelium rather than tumor cells to inhibit the growth of renal cell carcinoma. Cancer Res, v. 70, n. 3, p. 1053-62, 2010. 
20. KALAPURAKAL, J. A. et al. Management of Wilms' tumour: current practice and future goals. Lancet Oncol, v. 5, n. 1, p. 37-46, 2004.

21. KORBAKIS, D.; SCORILAS, A. Quantitative expression analysis of the apoptosis-related genes BCL2, BAX and BCL2L12 in gastric adenocarcinoma cells following treatment with the anticancer drugs cisplatin, etoposide and taxol. Tumour Biol, 2012.

22. KRAJEWSKI, S. et al. Reduced expression of proapoptotic gene BAX is associated with poor response rates to combination chemotherapy and shorter survival in women with metastatic breast adenocarcinoma. Cancer Res, v. 55, n. 19, p. 4471-8, 1995.

23. LAHOTI, 0. et al. Immunohistochemical detection of p53 in Wilms' tumors correlates with unfavorable outcome. Am J Pathol, v. 148, n. 5, p. $1577-89,1996$.

24. MEISTER, B. et al. Expression of vascular endothelial growth factor (VEGF) and its receptors in human neuroblastoma. Eur J Cancer, v. 35, n. 3, p. 445-9, 1999.

25. OLTVAI, Z. N.; MILLIMAN, C. L.; KORSMEYER, S. J. Bcl-2 heterodimerizes in vivo with a conserved homolog, Bax, that accelerates programmed cell death. Cell, v. 74, n. 4, 609-19, 1993.

26. RE, G. G. et al. Prognostic significance of Bcl-2 in Wilms' tumor and oncogenic potential of Bcl- $\mathrm{X}_{\mathrm{L}}$ in rare tumor cases. Int J Cancer, v. 84, n. 2, p. 192-200, 1999.

27. REINHARD, H. et al. Outcome of relapses of nephroblastoma in patients registered in the SIOP/GPOH trials and studies. Oncol Rep, v. 20, n. 2, p. 463 7,2008 .

28. RIVERA, M. N.; HABER, D. A. Wilms' tumour: connecting tumorigenesis and organ development in the kidney. Nature reviews. Cancer, v. 5, n. 9 , p. 699-712, 2005.

29. SKOTNICKA-KLONOWICZ, G. et al. Prognostic value of p53 expression in Wilms' tumor in children. Med Sci Monit, v. 7, n. 6, p. 1224-9, 2001.

30. SLONGO, M. L. et al. Functional VEGF and VEGF receptors are expressed in human medulloblastomas. Neuro Oncol, v. 9, n. 4, p. 384-92, 2007.

31. SREDNI, S. T. et al. Immunohistochemical detection of p53 protein expression as a prognostic indicator in Wilms tumor. Med Pediatr Oncol, v. 37, n. 5, p. $455-8,2001$

32. TAMMELA, T. et al. The biology of vascular endothelial growth factors. Cardiovasc Res, v. 65, n. 3, p. 550-63, 2005.

33. THOMADAKI, H.; SCORILAS, A. Molecular profile of the bcl2 family of the apoptosis related genes in breast cancer cells after treatment with cytotoxic/ cytostatic drugs. Connect Tissue Res, v. 49, n. 3, p. 261-264, 2008.

34. VUJANI, G. M. et al. Revised International Society of Paediatric Oncology (SIOP) working classification of renal tumors of childhood. Med Pediatr Oncol, v. 38, n. 2, p. 79-82, 2002.

35. WEEKS, D. A.; BECKWITH, J. B.; LUCKEY, D. W. Relapse-associated variables in stage I favorable histology Wilms' tumor. A repot of the National Wilms' tumor Study. Cancer, v. 60, n. 6, p. 1204-12, 1987. 